\title{
Inheritance of Fruit Quality Traits in Blueberry
}

\author{
Chad E. Finn ${ }^{1}$ and James J. Luby \\ Department of Horticultural Science, University of Minnesota, St. Paul, MN 55108
}

Additional index words. blueberry breeding, Vaccinium angustifolium V. corymbosum, partial diallel, combining ability, fruit color, fruit firmness, fruit picking scar

\begin{abstract}
Progenies from a partial diallel mating scheme using 17 highbush (Vaccinium corymbosum L.), lowbush ( $V$. angustifolium Ait.), and half-high $(V$. corymbosum $/ V$. angustfolium hybrid) parents were subjectively evaluated for fruit color, picking scar, and firmness in two seasons. General combining ability (GCA) mean squares were significant $(P \leq 0.01$ for all traits), but specific combining ability was significant for no traits $(P>0.05)$. However, the correlation coefficients between the GCA effects and the parental phenotype scores were low, indicating that selection of parents within this material based on their phenotype may not be indicative of progeny performance. GCA effects depended to some extent on the species ancestry. Vaccinium angustifolium parents produced progeny with relatively dark, soft fruit with large scars. Lowbush parents having light-blue fruit produced segregating progenies that were heavily skewed toward dark fruit, regardless of the color or species ancestry of the other parent. When the highbush and half-high parents were crossed with one another, segregation patterns were typical of predominately additive gene action.
\end{abstract}

Color, firmness, and size of the pedicel detachment scar (picking scar) are important components of fruit quality in blueberry (Vaccinium spp.) (Galletta, 1975). Previous reports suggest that the inheritance of fruit color varies, depending on whether crosses are intra- or interspecific. Inheritance of fruit color in lowbush blueberry has qualitative and quantitative components. In crosses between the black-fruited $V$. angustifolium var. $n i$ grum (Wood) Dole and the typical blue-fruited var, angustifolium, the "nigrum" phenotype is inherited as a single semidominant gene influenced by modifying genetic and environmental factors (Aalders and Hall, 1963). In a diallel cross of blue-fruited lowbush blueberry parents, Aalders and Hall (1975) concluded that the environmental component of variation for fruit color was large and also that genetic variation was large and mainly additive.

In highbush blueberry, crosses with one or both parents having light blue fruit produced many progeny with light blue fruit, and transgressive segregation was common (Coville, 1937; Darrow et al., 1939; Edwards et al., 1974; Johnston, 1942). Edwards et al. (1974) reported a narrow-sense heritability estimate of 0.59 for color, although year-to-year environmental variation resulted in inconsistent scoring. They concluded that parents chosen for their bright fruit color should transmit the desirable color characters to their progenies. Draper et al. (1982) crossed parents containing $V$. corymbosum, $V$. constablaei Gray, $V$. ashei Reade, V. tenellum Ait., and V. atrococcum Heller and found that the families usually segregated for fruit color with $10 \%$ to $47 \%$ being rated blue enough to be acceptable. They recorded their highest color ratings in backcrosses of interspecific hybrids to $V$. corymbosum. Ballington et al. (1986) noted large proportions $(39 \%$ to $97 \%$ ) of progenies with acceptable color in 11 of 13 crosses and backcrosses involving $V$. ashei and $V$. constablaei. In one primary interspecific cross and one backcross to $V$. ashei, epistasis for dark fruit color was observed.

Received for publication 22 Oct. 1991. Accepted for publication 18 Feb. 1992 Scientific Journal Series Paper no. 19,211. Minn. Agr. Expt. Sta., St. Paul. We gratefully acknowledge the efforts of C. Stushnoff and R. Stucker in designing and establishing the plantings used for this study. The cost of publishing this paper was defrayed in part by the payment of page charges. Under postal regulations, this paper therefore must be hereby marked advertisement solely to indicate this fact.

'Current address: Dept. of Horticulture, Univ. of Missouri, 1-40 Agriculture Building, Columbia, MO 65211
Interspecific crosses between highbush and lowbush parents produced few progeny with light blue fruit even when both parents had light blue fruit (Coville, 1937; Darrow et al., 1952; Johnston, 1946; Meader et al., 1954). Johnston (1946) found that $\approx 65 \%$ of the seedlings had dark fruit in crosses involving light blue-fruited lowbush selections and several highbush cultivars. This proportion was twice that he found in crosses among dark-fruited highbush parents (Johnston, 1942). In crosses between lowbush and highbush parents, where both parents had light blue fruit, seedlings ranged from black to medium blue (Darrow et al., 1952). In similar crosses where the lowbush parents had light blue fruit and the highbush parents had dark blue fruit, all progeny had black or dark-blue fruit.

Although little genetic variation for fruit scar was observed in several studies (Ballington et al., 1986; Darrow et al., 1952; Johnston, 1942), certain parents have been noted for producing progenies with superior scars (Darrow et al., 1939; Edwards et al., 1974; Johnston, 1956; Luby et al., 1990). Vaccinium angustifolium accessions had fruit scars of smaller depth and diameter than many $V$. corymbosum cultivars and wild accessions, but, in many cases, the interspecific differences were small (Ballington et al., 1984; Galletta, 1975). Edwards et al. (1974) found that year-to-year variation in scoring of highbush progenies was small. Parental performance and general combining ability (GCA) effects were highly correlated, but specific combining ability (SCA) variance components were much larger than GCA variance components.

Highbush and lowbush blueberries can be quite variable for firmness (Ballington et al., 1984; Coville, 1937; Draper et al., 1982; Galletta, 1975; Johnston, 1942, 1946), Ballington et al. (1984) reported that the fruit of $V$. angustfolium tended to be less firm than fruit of $V$. corymbosum. Draper et al. (1982) rated $84 \%$ of the seedlings derived from $V$. corymbosum as having acceptable firmness. Although the parental phenotype for firmness has been predictive of progeny performance in $V$. corymbosum (Edwards et al., 1974; Johnston, 1942), Johnston (1942) found that the proportion of seedlings with acceptable firmness from crosses among acceptable highbush parents ranged from $16 \%$ to $63 \%$. Edwards et al. (1974) reported that GCA variance was much larger than the SCA variance and that firmness scoring was not repeatable from year to year in low-chilling tetraploid progenies.

At the Univ. of Minnesota, the goal of the blueberry breeding program has been to combine the productivity, fruit size, and 
desirable fruit quality components from the highbush blueberry, $V$. corymbosum, with the lower stature and cold hardiness of the lowbush blueberry, V. angustifolium (Luby, 1991; Stushnoff, 1976). We have previously reported on the quantitative inheritance of cold hardiness, plant stature, fruit size, and traits related to productivity in blueberry germplasm derived from $V$. corymbosum and $V$. angustifolium (Fear et al., 1985; Finn and Luby, 1986; Luby and Finn, 1986, 1987). In this study, our objective was to estimate the relative magnitudes of genetic and environmental effects for the subjectively evaluated fruit quality traits of color, firmness, and picking scar to provide guidance for improving efficiency of selection and planning of future crosses.

\section{Materials and Methods}

Each of 17 parents was crossed with six other parents in a circulant partial diallel mating design (Kempthorne and Curnow, 1961). The resulting 51 progenies were planted at Becker, Minn., in 1976. The progenies were planted in a randomized complete-block design with four replications and 12 seedlings per plot at a spacing of $1.2 \mathrm{~m}$ within the row and $2.4 \mathrm{~m}$ between the rows. Single parental plants, except N70220 (which died), were grown in an adjacent field. The parents were tetraploid $(2 \mathrm{n}=4 \mathrm{x}=48)$ lowbush and highbush genotypes and "halfhigh" selections derived from $V$. angustifolium and $V$. corymbosum (Table 1).

In 1985 and 1986, fruit from each plant were rated on a 1 to 9 scale for color $(1=$ black, $9=$ bright blue $)$, picking scar $(1$ = large, deep, with torn skin, $9=$ small, dry), and firmness
( 1 = very soft, $9=$ very firm) similar to scales employed by other researchers (e.g., Ballington et al., 1986; Draper et al., 1982; Edwards et al., 1974). The ratings were made in the field based on a sample of five to eight berries from each plant when at least $50 \%$ of the fruit were ripe.

Analyses of variance were computed for a randomized complete block as a split plot in time. The F values were calculated using the appropriate mean squares, assuming a mixed model with years as a fixed effect and crosses and replications as random effects. The Satterthwaite approximation (Satterthwaite, 1946) was used where necessary to calculate F values. No seedlings survived from one cross, so only 50 crosses were used in analyses. Because of our interest in parental contributions in this germplasm, GCA effects were calculated under the assumptions of a fixed effects model (Baker, 1978; Fear et al., 1985 ).

\section{Results and Discussion}

The parents had medium to light-blue fruits (ratings of 6.0 to 8.5 ) except for the $V$. angustifoliuml/ $V$. corymbosum hybrids MN61, which had dark blue fruit (rating 4.5), and GR2, which had nearly black fruit (rating 1.5) (Table 1). The parents were variable for scar and firmness (Table 1). Several of the $V$. corymbosum parents (B10, B11, B16, and B1-1) had large fruit scars. The two $V$. angustifolium parents, GRVa and N70249, had relatively soft fruit.

GCA mean squares for color, scar, and firmness were significant $(P \leq 0.01)$ and several times larger than the nonsignificant $(P>0.05)$ mean squares for SCA (Table 2). The

Table 1. Identification of parents (listed from highest to lowest proportion of putative Vaccinium angustifoliuim ancestry) of the partial diallel cross and ratings ${ }^{\mathrm{z}}$ of single parent plants for fruit color, scar, and firmness (means over 1985-86).

\begin{tabular}{|c|c|c|c|c|}
\hline Parent & Ancestry & Color & Scar & Firmness \\
\hline N70249y,x & V. angustifolium & 8.5 & 7.5 & 3.0 \\
\hline GRVay & $V$. angustifolium & 8.0 & 5.0 & 3.0 \\
\hline $\mathrm{R} 2 \mathrm{P} 4^{\mathrm{w}}$ & $V$. angustifolium $\times V$. corymbosum & 7.5 & 5.5 & 7.0 \\
\hline GR1w & $V$. angustifolium $\times V$. corymbosum & 6.0 & 5.5 & 7.0 \\
\hline GR2 $2^{w}$ & $V$. angustifolium $\times V$. corymbosum & 1.5 & 6.5 & 6.0 \\
\hline MN61 & $\begin{array}{l}V . \text { corymbosum (USDA 11-93) } \times V \text {. } \\
\text { angustifolium var. nigrum }\end{array}$ & 4.5 & 7.0 & 7.0 \\
\hline Northsky & B6 $\times$ R2P4 & 7.5 & 7.5 & 5.5 \\
\hline Northcountry & B6 $\times$ R2P4 & 7.5 & 7.5 & 6.5 \\
\hline MN84 & $\begin{array}{l}\text { B16 x US3 (Dixi x Mich. } \\
\text { Lowbush No. 1) }\end{array}$ & 6.0 & 6.5 & 5.5 \\
\hline Bluetta & $\begin{array}{l}\text { (North Sedgewick lowbush } \times \\
\text { Coville) } \times \text { Earliblue) }\end{array}$ & 7.5 & 4.5 & 5.5 \\
\hline N70218v & V. corymbosum & 6.5 & 7.5 & 5.5 \\
\hline $\mathrm{N} 70220^{\mathrm{v}}$ & V. corymbosum & -. & $\cdots$ & - \\
\hline B16 & $V$. corymbosum (G65 $\times$ Ashworth) & 7.0 & 4.0 & 4.5 \\
\hline B10 & V. corymbosum (G65 $\times$ Ashworth) & 7.0 & 4.5 & 6.5 \\
\hline B6 & V. corymbosum (G65 $\times$ Ashworth) & 6.5 & 7.0 & 7.0 \\
\hline B11 & $V$. corymbosum (G65 $\times$ Ashworth) & 7.0 & 5.0 & 5.5 \\
\hline B1-1 & V. corymbosum (G65 $\times$ Ashworth) & 7.5 & 5.0 & 5.0 \\
\hline
\end{tabular}

${ }^{\mathrm{z}}$ Rating scales for color, scar, and firmness ranged from 1 = black fruit, large and deep scar, or very soft; $9=$ light blue fruit, small and dry scar, or very firm, respectively (Ballington et al., 1986).

'Collected from a wild stand in northern Minnesota.

${ }^{\mathrm{x}} \mathrm{N}$ prefix indicates an accession; $\mathrm{MN}, \mathrm{B}$, and GR prefixes indicate selections in the Minnesota program. USDA 11-93, US3, and G65 are selections from the U.S. Dept. of Agriculture blueberry breeding program.

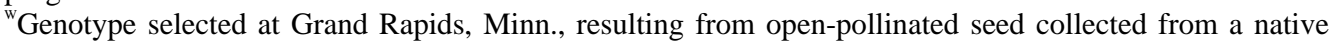
half-high plant in the Harvard Forest, Mass.

${ }^{v}$ Genotype provided by F. Ashworth, Heuvelton, N.Y.; appears to be mainly V. corymbosum with some V. angustifolium characters. 
Table 2. Analysis of variance for fruit color, firmness, and scar ratings for partial diallel mating design.

\begin{tabular}{lrccl}
\hline \hline & & \multicolumn{3}{c}{ Mean squares } \\
\cline { 3 - 5 } Source & df & Color & Scar & Firmness \\
\hline Replications & 3 & 0.57 & $6.95^{* *}$ & 1.84 \\
Crosses & 49 & $14.51^{* *}$ & $2.30^{* *}$ & $3.41^{* *}$ \\
GCA & 16 & $39.20^{* *}$ & $4.86^{* *}$ & $8.45^{* *}$ \\
SCA & 33 & 2.52 & 1.05 & 0.97 \\
Rep. $\times$ crosses & 147 & 0.88 & $0.66^{* *}$ & $0.94^{* *}$ \\
Years & 1 & $17.68^{* *}$ & $169.11^{* *}$ & 0.23 \\
Crosses $\times$ years & 49 & $0.55^{* *}$ & 0.57 & $1.04^{* *}$ \\
Error & 150 & 0.36 & 0.48 & 0.50 \\
\hline
\end{tabular}

${ }^{* *}$ F-value $>1(P \leq 0.01)$.

Table 3. General combining ability effects ${ }^{2}$ of blueberry parents for fruit color, firmness, and scar (1985-86).

\begin{tabular}{lrrr}
\hline \hline Parent & Color & Scar & Firmness \\
\hline N70249 & -2.1 & -0.6 & -0.8 \\
GRVa & -1.9 & -0.5 & -0.2 \\
R2P4 & 0.2 & -0.2 & 0.1 \\
GR1 & 0.3 & 0.2 & -0.2 \\
GR2 & -1.3 & 0.0 & 0.6 \\
MN61 & -0.6 & 0.2 & -0.7 \\
Northsky & 0.7 & 0.4 & -0.4 \\
Northcountry & 0.5 & 0.2 & 0.1 \\
MN84 & 0.2 & 0.5 & -0.2 \\
Bluetta & 0.9 & 0.3 & 0.6 \\
N70218 & 0.5 & 0.0 & 0.1 \\
N70220 & 0.6 & -0.3 & 0.4 \\
B16 & 0.2 & -0.4 & -0.4 \\
B10 & 0.0 & 0.0 & 0.7 \\
B6 & 0.7 & 0.3 & 0.2 \\
B11 & 0.4 & -0.2 & 0.2 \\
B1-1 & 0.9 & 0.0 & -0.1 \\
SE & 0.2 & 0.2 & 0.2 \\
\hline
\end{tabular}

${ }^{\mathrm{z}}$ Rating scales for color, scar, and firmness ranged from 1 = black fruit, large and deep scar, or very soft; 9=light-blue fruit, small and dry scar, or very firm, respectively (Ballingtonet al., 1986).

significant variation for scar and firmness in this germplasm contrasts with a lack of genetic variation detected in several inheritance studies with other parental populations (Ballington et al., 1986; Darrow et al., 1939; Draper et al. 1982; Edwards et al., 1974). The crosses $\times$ years interactions were also significant $(P \leq 0.01)$ for color and firmness, indicating differential performance of some crosses each year in response to the environmental effects. Year-to-year variation in scores was substantial for color and scar but not firmness. Edwards et al. (1974) found year-to-year variation in scoring color and firmness but not scar. Such annual variation in scoring could be due to environmental factors (e.g., temperature and rainfall) or to inconstancy in the subjective scale.

The light blue-fruited V. angustifolium parents (N70249 and GRVa) had large negative GCA effects for fruit color (Table 3) indicative of the preponderance of dark fruit color in their progenies. Two $V$. angustifolium/V. corymbosum hybrids (MN61 and GR2) with dark fruit had smaller negative GCA effects for fruit color. The other parents that were either $V$. corymbosum or species hybrids had negligible (R2P4, GR1, B10, B16) or positive ('Northsky', 'Northcountry', B6, B11, B1-1, N70218, N70220, 'Bluetta') effects for color in their progenies.

The two V. angustifolium parents (N70249 and GRVa) and one $V$. corymbosum parent (B16) produced progenies with large scars (Table 3). N70249 had a small scar, but GRVa and B16 had large scars (Table 1). Two species hybrids ('Northsky' and MN84) contributed to desirable scars in their progeny (Table $3)$.

In general, the parents with large amounts of $V$. angustifolium ancestry (N70249, GRVa, MN61, GR1, and 'Northsky') produced offspring with softer fruit than parents with larger amounts of $V$. corymbosum ancestry (B6, B10, B11, N70218, N70220, and 'Bluetta') (Table 3). However, this relationship with species ancestry was obscured in some cases. For instance, GR2, an interspecific hybrid, had firm-fruited progenies, while B16, a $V$. corymbosum derivative, had relatively soft-fruited progenies.

The correlation coefficients between the GCA effects and the parental phenotype scores were low for color, scar, and firmness ( $r=0.17,0.28$, and 0.45 , respectively; all $P>0.05$ ), indicating that variation in progeny performance is not reliably predicted by parental phenotype in this material. This contrasts with studies in highbush blueberries where parental performance was a good indicator of progeny performance (Coville, 1937; Darrow et al., 1939; Edwards et al., 1974; Johnston, 1942, 1956). The low correlation for fruit color may be due largely to the anomalous behavior of the two light blue-fruited $V$. angustifolium parents that yielded progenies with dark fruit.

The partial diallel mating scheme consisted of four types of crosses: lowbush $\times$ half-high, lowbush $\times$ highbush, highbush $\times$ half-high, and highbush $\times$ highbush. Among these types of crosses, two segregation patterns for fruit color were exhibited, similar to those observed by other researchers (Coville, 1937; Darrow et al., 1939, 1952; Johnston, 1946; Meader et al., 1954). The first pattern occurred in any cross involving a $V$. angustifolium parent. When either of the light-blue lowbush parents (N70249, GRVa) was used, the progeny segregation was strongly skewed toward dark fruit, regardless of the color or species ancestry of the other parent (Fig. 1 a-d). This result is in agreement with previous studies (Coville, 1937; Darrow et al., 1939; Johnston et al., 1946; Meader et al., 1954).

The second pattern, observed when both parents were $V$. corymbosum or $V$. angustifolium/ $V$. corymbosum hybrids, was typical of additive gene action. Progeny tended to be normally distributed between the two parental means with some transgressive segregates. For example, when light-blue highbush parents $($ B6 $\times$ B 1-1) or interspecific hybrids $($ N70218 $\times$ 'Northcountry') were crossed with one another, most of the offspring segregated around the high parental rating (Fig. 1 e,f). When a dark-blue interspecific hybrid was crossed with a lightblue interspecific hybrid (GR2 $\times$ 'Northcountry') or highbush parent $(\mathrm{GR} 2 \times \mathrm{B} 16)$, the progeny ranged between and around the parental scores (Fig. $1 \mathrm{~g}, \mathrm{~h}$ ). Segregation for fruit color in these crosses demonstrated, as in previous studies (Coville, 1937; Darrow et al., 1952; Johnston, 1946; Meader et al., 1954), that progeny with acceptable color can be recovered in later generations of interspecific hybridization even when a dark-fruited parent is used.

Improvement of scar and firmness in this germplasm should be possible, though perhaps difficult. Although the GCA variance components were large compared with genotype $\times$ environment interactions, the parental phenotype did not accurately predict a progeny performance. Vaccinium angustifolium may contribute small scar size, but direct crosses with the species should be minimized, as two or more generations are needed to recover progeny with light-blue fruit. 

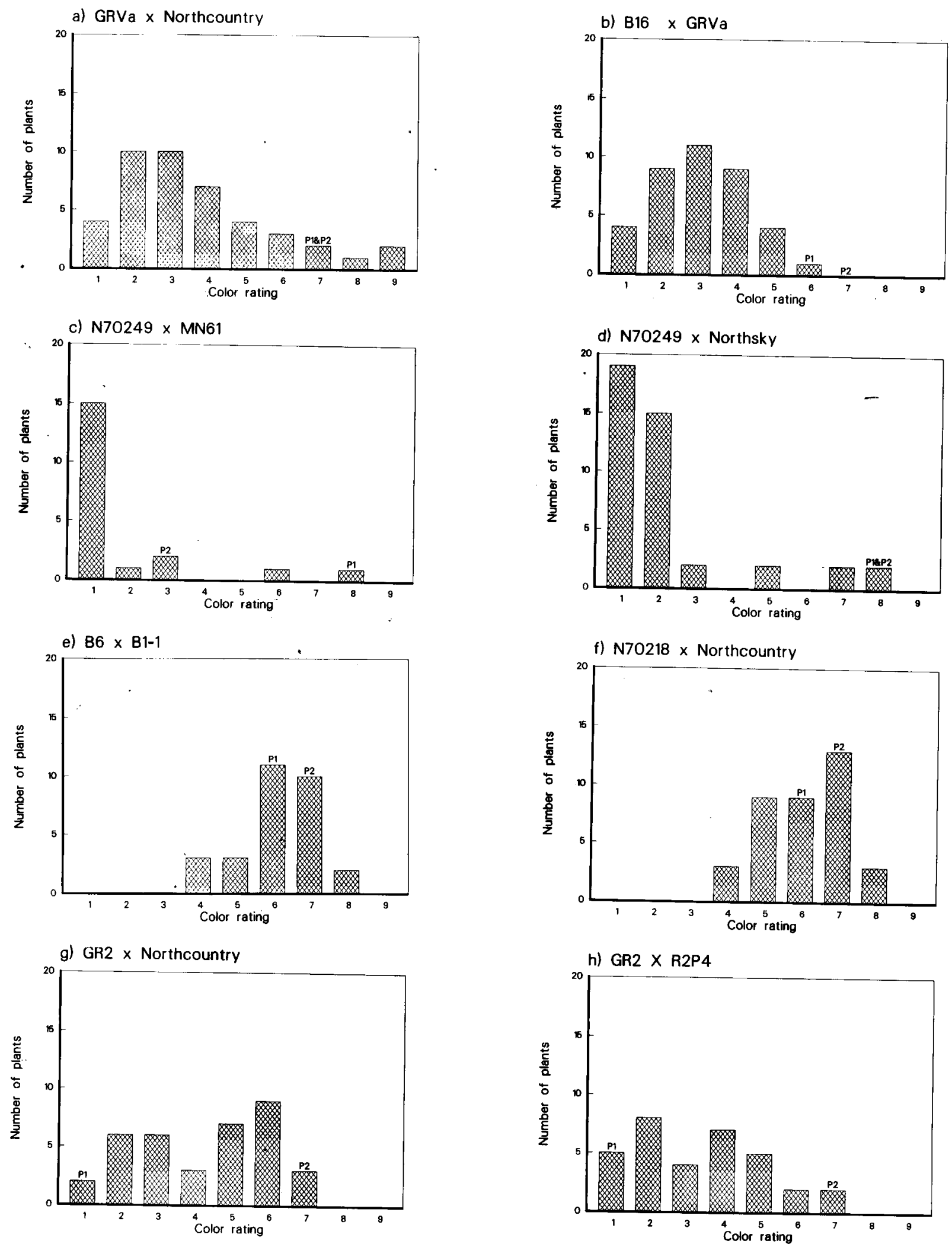

Fig. 1. Examples of segregation patterns for fruit color in blueberry crosses involving Vaccinium angustifolium parents (a-d) or V. corymbosum and interspecific hybrid parents (e-h). The rating scale for fruit color ranged from $1=$ black fruit to $9=$ light-blue fruit. Ratings of female and male parents are indicated by $\mathrm{P} 1$ and $\mathrm{P} 2$, respectively. 


\section{Literature Cited}

Aalders, L.E. and I.V. Hall. 1963. The inheritance and taxonomic significance of the 'nigrum' factor in the common lowbush blueberry, Vaccinium angustifolium. Can. J. Genet. Cytol. 5:115-118.

Aalders, L.E. and I.V. Hall. 1975. A study of variation in fruit yield and related characters in two diallels of the low bush blueberry, Vaccinium angustifolium Ait. Can. J. Genet. Cytol. 17:401-404.

Baker, R.J. 1978. Issues in diallel analysis. Crop Sci. 19:533-535.

Ballington, J.R., W.E. Ballinger, W.H. Swallow, G.J. Galletta, and L.J. Kushman. 1984. Fruit quality characterization of 11 Vaccinium species. J. Amer. Soc. Hort. Sci. 109:684-689.

Ballington, J.R., Y.M. Isenberg, and A.D. Draper. 1986. Flowering and fruiting characteristics of Vaccinium ashei and Vaccinium asheiVaccinium constablaei derivative blueberry progenies. J. Amer. Soc. Hort. Sci. 111:950-955.

Coville, F.V. 1937. Improving the wild blueberry. U.S. Dept. Agr. Yrbk. Agr. 1937:559-574.

Darrow, G.M., J.H. Clark, and E.B. Morrow. 1939. The inheritance of certain characters in the cultivated blueberry. Proc. Amer. Soc. Hort. Sci. 37:611-616.

Darrow, G.M., E.B. Morrow, and D.H. Scott. 1952. An evaluation of interspecific blueberry crosses. Proc. Amer. Soc. Hort. Sci. 59:277282.

Draper, A.D., G.J. Galletta, and J.R. Ballington. 1982. Breeding methods for improving southern tetraploid blueberries. J. Amer. Soc. Hort. Sci. 107:106-109.

Edwards, T.W., W.B. Sherman, and R.H. Sharpe. 1974. Evaluation and inheritance of fruit color, size, scar, firmness and plant vigor in blueberry. HortScience 9:20-22.

Fear, C.J., F.I. Lauer, J.J. Luby, R.L. Stucker, and C. Stushnoff. 1985. Genetic components of variance for winter injury, fall growth cessation, and off-season flowering in blueberry progenies. J. Amer. Soc. Hort. Sci. 110:262-266.
Finn, C.E. and J.J. Luby. 1986. Inheritance of fruit development interval and fruit size in blueberry progenies. J. Amer. Soc. Hort. Sci. 111:784-788.

Galletta, G.J. 1975. Blueberries and cranberries, p. 154-196. In: J. Janick and J.N. Moore (eds.). Advances in fruit breeding. Purdue Univ. Press, West Lafayette, Ind.

Johnston, S. 1942. Observations on the inheritance of horticulturally important characteristics in the highbush blueberry. Proc. Amer. Soc. Hort. Sci. 40:352-356.

Johnston, S. 1946. Observations on hybridizing lowbush and highbush blueberries. Proc. Amer. Soc. Hort. Sci. 47:199-200.

Johnston, S. 1956. Blueberry breeding in Michigan. Fruit Var. Hort. Dig. 11:20.

Kempthome, O. and R.N. Curnow. 1961. The partial diallel cross. Biometrics 17:229-250.

Luby, J.J. 1991. Breeding cold-hardy fruit crops in Minnesota. HortScience 26:507-512.

Luby, J.J.; J.R. Ballington, A.D. Draper, K. Pliszka, and M.E. Austin. 1990. Blueberries and cranberries (Vaccinium), p. 391456. In: J.N. Moore and J.R. Ballington (eds.). Genetic resources of temperate fruit and nut crops. Intl. Soc. Hort. Sci., Wageningen, The Netherlands.

Luby, J.J. and C.E. Finn. 1986. Quantitative inheritance of plant growth habit in blueberry progenies. J. Amer. Soc. Hort. Sci. 111:609-611.

Luby, J.J. and C.E. Finn. 1987. Inheritance of ripening uniformity and relationship to crop load in blueberry progenies. J. Amer. Soc. Hort. Sci. 112:167-170.

Meader, E.M., W.W. Smith, and A.F. Yeager. 1954. Bush types and fruit colors in hybrids of highbush and lowbush blueberries. Proc. Amer. Soc. Hort. Sci. 63:272-278.

Satterthwaite, F.E. 1946. An approximate distribution of estimates of variance components. Biometrics Bul. 2:110-114.

Stushnoff, C. 1976. Development of cold hardy blueberry hybrids. Fruit Var. J. 30:28-29. 